\title{
ARE SPINAL CORD INJURY PATIENTS MORE PRONE TO CONTRAST REACTIONS?
}

\author{
By A. T. Scher, M.B., Ch.B., D.M.R.D. \\ Department of Radiology and Spinal Cord Injuries Centre, Conradie Hospital, Cape Town, \\ South Africa
}

\begin{abstract}
A previous investigation has indicated that spinal cord injury patients are more prone to develop reactions to intravenous contrast media. An investigation into the incidence of contrast reaction in I00 spinal cord injury patients undergoing intravenous pylography together with the incidence in a control group of I00 non-paraplegic patients, has been made. This has shown that spinal cord injury patients do not have a higher incidence of reaction. The aetiology of contrast reaction is briefly discussed with particular reference to the paraplegic patient.
\end{abstract}

Key words: Spinal cord injury; Intravenous pylography.

\section{Introduction}

IN 1962 Simpson et al. reported that reaction to the injection of contrast medium during intravenous pylography was significantly higher in paraplegic patients. Although a large number of intravenous pylograms are performed annually on both paraplegic and non-paraplegic patients at this hospital, this has not been our impression.

Intravenous pylography, which is performed annually on all paraplegic patients in the care of the Spinal Cord Injuries Centre, is an essential part of the investigations into the status of the urinary tract. Should paraplegic patients be more susceptible to contrast reaction, this would be an unfortunate extra complication. It is well known that patients with spinal injuries involving the cervical and upper thoracic spinal cord are exposed to the hazard of autonomic hyperreflexia during some radiological procedures, particularly cystography. In order to ascertain the true incidence of contrast reaction in paraplegic as compared to non-paraplegic patients, a comparative study has been undertaken.

\section{Methods and Materials}

The incidence and type of reaction was recorded in Ioo consecutive patients with spinal cord injury and Ioo ordinary hospital patients without evidence of spinal cord disease. The spinal cord injury patients were unselected and comprised of both male and female, all of whom had sustained trauma to the spinal cord with resultant paralysis. The degree of paralysis varied from incomplete to complete paraplegia or tetraplegia.

The non-paraplegic patients received the standard preparation prior to examination. They were instructed to have no food or fluids on the morning of examination and were provided with oral aperients for use the day before the intravenous pylogram. The paraplegic patients were similarly starved, but received bowel wash-outs on the morning of examination instead of oral aperients. Both groups were administered $40 \mathrm{ml}$ sodium iothalomate (Conray 325 ) by slow intravenous injection. No premedication of antihistamines or other preparation was provided. 


\section{Results}

The incidence of reaction was similar in both groups, as shown in Table I. All reactions were minor in nature, the commonest being nausea often accompanied by vomiting. Other reactions were dryness of the mouth, a feeling of warmth, and pain in the arm on the side of injection.

There was no relationship between the level of spinal cord injury and the incidence of contrast reaction. Nor was there any relationship between the degree of paralysis and the incidence of reaction. The incidence of reaction was not significantly higher in those patients who had had previous uneventful intravenous pylography.

\section{Discussion}

Ansell (1976) reviewed the problem of reaction to the intravenous administration of contrast media, and suggested that reactions be considered in three main categories as follows:

I. Idiosyncrasy reactions in a susceptible patient from a dose of contrast medium which would be harmless to most patients.

2. Reactions following the use of a large dose of contrast in high-dose urography or angiography.

3. Reactions occurring when a concentrated bolus of contrast has been delivered to a critical area such as the myocardium, brain, spinal cord or kidneys.

The reactions in the last two categories are directly due to the chemotoxicity and hypertonicity of excessive doses of contrast media. The dosage of contrast used in this series, and in the investigation of Simpson et al. (1962) was well below the level needed to produce direct toxic effects in the adult patient. The minor reactions encountered in this series can therefore be considered as 'Idiosyncrasy reactions'.

The aetiology of idiosyncratic contrast reaction is poorly understood and several factors are probably involved. These reactions were originally considered to be allergic, but definite evidence of a constant immunological response in patients with contrast reactions has not been found. Occasional cases have been noted in which the history suggested the development of true hypersensitivity to contrast medium (Ansell, I970).

Recently it has been shown that small quantities of free iodine may be present in contrast medium, Coel et al. (1975), and that certain types of reaction (conjuctival injection, rhinorrhoea, salivary gland enlargement and delayed skin rash) may be due to true iodism.

\section{TABLE I}

Number and per cent of patients with reactions during intravenous pylography

\begin{tabular}{lccc}
\hline & $\begin{array}{c}\text { Total no. of } \\
\text { patients }\end{array}$ & $\begin{array}{c}\text { No. of patients } \\
\text { with reactions }\end{array}$ & $\begin{array}{c}\text { Per cent of patients } \\
\text { with reactions }\end{array}$ \\
Paraplegic patients & I00 & $3 \mathrm{I}$ & $3 \mathrm{I}$ \\
Non-paraplegic patients & I00 & 30 & 30 \\
\hline
\end{tabular}


The results of this investigation were not in keeping with the findings of Simpson et al. There was no higher incidence of contrast reaction in spinal cord injury patients, the incidence being virtually the same in both groups. A lower percentage of reactions (3I per cent) was present in our group of spinal cord injury patients than was found by Simpson et al., who reported a 47 per cent incidence.

Our findings were similar to those of Simpson et al. in that no relationship between the incidence of reaction and the level of spinal cord injury was evident. This would confirm that autonomic hyperreflexia is not a factor in producing contrast reaction in the paraplegic patient. Simpson et al. attributed their findings. to two factors, one being a sensitisation tendency following repeated examinations. We did not find an increased tendency to contrast reaction in patients who had previously undergone intravenous pylography without reaction.

As previously indicated, definite evidence of an allergic basis to contrast reaction has not been found. Sandstrom (1955) pointed out that reactions may occur in patients who have not been exposed to a sensitising dose of contrast medium. The risk of recurrence of contrast reaction is approximately 35 per cent (Witten et al., I973). These authors found that even in patients who had previously experienced reactions, recurrence was inconsistent, being present on some occasions and not on others.

The second factor considered by Simpson et al. as being responsible for the higher incidence of contrast reaction, was the 'general metabolic alteration in the paraplegic patient'. Reference to the literature does not reveal any metabolic disturbance peculiar to paraplegic patients which would render them more liable to reaction than non-paraplegic patients. For the above reasons it is difficult to evaluate the validity of Simpson et al.'s supposition.

\section{RÉSUMÉ}

Une étude antérieure a montré que des malades souffrant d'un accident à la moëlle épinière ont plus de risques de déveloper des reactions si l'on examine une radio intraveneuse avec contrastes. Une étude à eté faite l'incidence lors de ces radios dans Ioo accidentes de la moëlle épinière qui subissent une pyélographie intraveneuse comparé à l'incidence dans un groupe de control de roo malades non-paraplégiques. Ceci demontre que des accidentes a la moëlle épinière n'ont pas une plus grande incidence de reaction. L'aetiologie de ce type de reaction est discutee brievement avec référence specifique aux malades paraplégiques.

\section{ZUSAMMENFASSUNG}

Die vorliegende Untersuchung zeigte, dass paraplegische Patienten dazu geneigt sind, Reaktionen auf intravenöse 'contrast media' zu entwickeln. Eine Studie wurde über die Häufigkiet der 'contrast' Reaktion von Ioo paraplegischen Patienten bie intravenösen Pyelographien gemacht, zusammen mit der Haüfigkeit in einer Kontrollgruppe von 100 nicht-paraplegischen Patienten. Diese Untersuchung ergab, dass paraplegische Patienten keine höhere Haüfigkeit der Reaktionen haben. Die Ätiologie der 'contrast Reaktion' wird im Zusammenhang mit paraplegischen Patienten kurz beschrieben.

\section{REFERENCES}

ANSELl, G. (1970). Adverse reactions to contrast agents. Invest. Radiol., 5, 374. ANSELl, G. (1976). Complications in Diagnostic Radiology. Blackwell Scientific Publications, Oxford.

Coel, M. N., Talner, L. B. \& Lang, J. H. (I975). Mechanism of radioactive iodine uptake depression following intravenous urography. Br.F. Radiol., 45, I9. 
SANDSTROM, C. (I955). Secondary reactions from contrast media and the allergy concept. Acta Radiol., 44, 233.

Simpson, K. H., COTTRELl, T. L. C. \& Lloyd, F. A. (I962). Intravenous pylography in the spinal cord injury patient. Amer. F. Surg., 103, 217.

Witten, D. M., Hirsh, F. D. \& HARTMAN, G. W. (I973). Acute reactions to urographic contrast medium. Incidence, clinical characteristics and relationship to history of hypersensitivity states. Amer. F. Roentg., I19, 832. 